\title{
Process and Equipment Improvement for Nickel Brush Plating Application
}

\author{
Martin Marek ${ }^{1}$, Martin Novak ${ }^{1}$, Tomas Rytina ${ }^{2}$, Numan M. Durakbasa ${ }^{3}$ \\ ${ }^{1}$ Faculty of Production Technology and Management, J. E. Purkyně University in Usti nad Labem, Pasteurova 3334/7, \\ 40001 Ústí nad Labem, Email: marek@fvtm.ujep.cz,novak@fvtm.ujep.cz \\ ${ }^{2}$ Solar Turbines EAME s.r.o, Tatinna c. p. 59, Bitozeves, Prumyslova zona Triangle, 43801 Zatec, E-mail: Rytina_To- \\ mas@solarturbines.com \\ ${ }^{3}$ Department for Interchangeable Manufacturing and Industrial Metrology and Nanometrology Laboratory, Institute for \\ Production Engineering and Laser Technology. Vienna University of Technlogy. 1060 Wien, Getreidemarkt 9, BA \\ 09/3113. E-mail: durakbasa@ift.tuwien.ac.at
}

The purpose of this paper is to provide an overview of process and equipment improvements for nickel brush plating applications. At the beginning of this project the company used methodology from a subsidiary which does nickel brush plating. Over time, it turned out that it would require a total redesign of the process, because it wasn't compliant with Czech legislation. We knew that without improvements the process could not move forward, therefore, we mainly focused on safety, equipment, accuracy and better quality. In this work we have been using many elements from quality management such as 6Sigma methodology, Ishikawa diagrams, 5why methods, 5S, etc.

This project included many people from different sectors such as designers, technicans, material engineers, facility and maintenance, production, quality engineers, EHS engineers etc. This team came with a completely new and unique technical solution for the covered equipment which had never been built in the past in this company or by brush plating process.

Keywords: nickel, environment, ergonomic, construction, safety

\section{Acknowledgement}

This projekt was supported by company Solar Turbines EAME Ltd., specific research supported under Ministry of Education, Youth and Sports and Project "Research on Achievement and Evaluation of High Precision of Machinned Surfaces" No. 7AMB16AT039.

\section{Reference}

[1] KRAUS, V. (2000). Surfaces and their modifications. Pilsen: University of West Bohemia in Pilsen, 2000, 218 pp. ISBN 80-7082-668-1.

[2] MAREK, M. (2015). Optimizing cutting conditions for grinding of rotor disk. Master Thesis. UJEP Usti nad Labem. 2015. 38s

[3] MAREK, M., NOVAK M. Evalution of Microhardness and Microstucture during Changing Cutting Conditions after Grinding Nickel Coating, Strojirenska technologie, Vol. XXI., June 2016, No. 1, pp. 26-33, ISSN $1211-4162$

[4] MAREK, M., NOVAK M. Evalution of Microhardness and Microstucture during Changing Cutting Conditions after Grinding Nickel Coating, Strojirenska technologie, Vol. XXI., June 2016, No. 1, pp. 26-33, ISSN 1211-4162

[5] DIBARI, G. A. Nickel Electroplating Applications and Trends, Plating and surface finishing, Vol. 83, No.10, ISSN: 0360-3164

[6] MAREK, M., NOVAK, M. (2016). Evaluation of Microstructure and Microstructure after Nickel Coating under Cutting Conditions, Strojirenska technologie, Vol. XXI., December 2016, No. 2, pp. 87-94, ISSN 1211-4162

[7] TULKA, J. (2005). Surface treatment of materials. Ed. 1. Brno: Brno University of Technology, Faculty of Chemistry, 2005.

[8] CSN EN 12540, January 2001, Metal Protection Against Corrosion - Electrolytically Excluded Plating of Nickel, Nickel-Chromium, Nickel-Nickel and Nickel-Chromium. The norm was issued in January 2001, published by Czech Standards

[9] NOVÁK, M., NÁPRSTKOVÁ, N. (2015). Grinding of the Alloy INCONEL 718 and Final Roughness of the Surface and Material Share. In: Manufacturing Technology, Vol. 15, No. 6, pp. 1015-1023

[10] BELAN, J., KUCHARIKOVÁ, L., TILlOVÁ, E., UHRÍČIK, M. (2015). The Overview of Intermetallic Phases Presented in Nickel Base Superalloys after Precipitation Hardening. In: Manufacturing Technology, Vol. 15, No. 4, pp. 509-515 
[11] MADLOVA, D., SKRIVAN,G. (2016) Occupational Health and Safety Hazards in Machining. In: Manufacturing Technology, Vol. 16, No.4, pp. 740-743

[12] BELAN, J., HURTAlOVA, L., VASKO, A., TILlOVA, E. (2014). Metallography Evaluation of IN 718 after Applied Heat Treatment. In: Manufacturing Technology,Vol. 14, No. 3, pp. 348-354

[13] HRUSKA, Z., DVORÁKOVA L. (2015) The Research Results in the Area Of Environmental Taxation of Manufacturing Business Entities in the Czech Republic. In: Manufacturing Technology, Vol. 15, No. 3, pp. 339-344

\section{Paper number: M201791}

Copyright $($ 2017. Published by Manufacturing Technology. All rights reserved. 